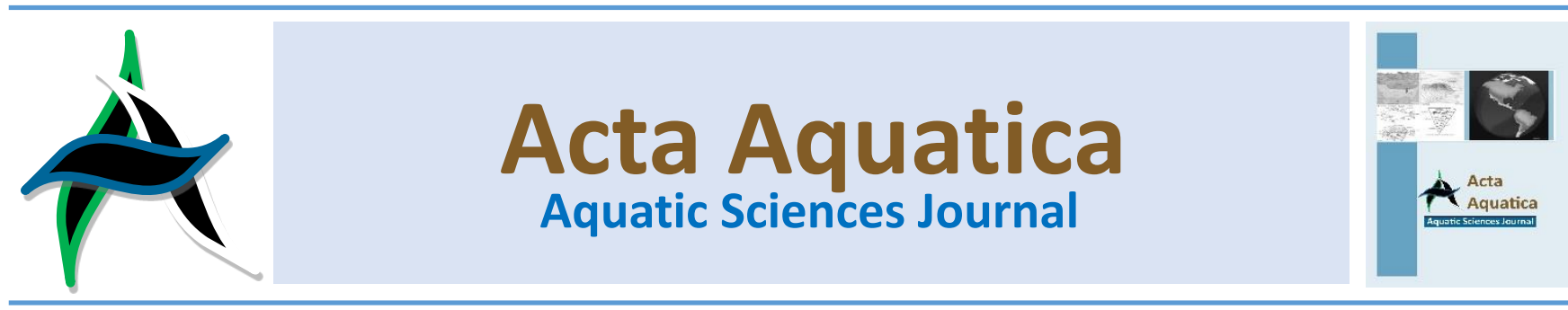

\title{
Infestation rate and impacts of Epipenaeon ingens on growth and reproduction of brown shrimp (Penaeus aztecus)
}

\author{
Mehmet Gökoğlu ${ }^{\text {a, * }}$, Serkan Teker ${ }^{a}$, and Jale Korun ${ }^{a}$ \\ ${ }^{a}$ Faculty of Fisheries, Akdeniz University, Turkey
}

\begin{abstract}
In this study, 515 Farfantepenaeus aztecus specimens were investigated in the Gulf of Antalya and 304 (59,02\%) specimens (167 females and 137 males) infested with Bopyrid isopod parasite Epipenaeon ingens were found. In this study, we aimed to define the rate of infestation and its impact on survival rate and growth rate. Relationship of length- weight and condition factor values were lower in infested specimens compared to non-infested ones. While gonadal development was observed in different stages of non-infested female specimens, no gonadal development was observed in any infested specimens. Moreover, darker color and harder shell structure were observed in parasitized shrimps. During this research, infestation onto $P$. semisulcatus and $P$. kerathurus had been seen rarely.
\end{abstract}

Keywords: Gulf of Antalya; Epipenaeon ingens, Farfantepenaeus aztecus; growth; reproduction

\section{Introduction}

Epipenaeon ingens Nobili (1906) is a Bopyrid isopod parasite and mainly known from the Indian and Western Pacific Ocean. Bopyrid isopods are branchial parasites from subfamily Orbioninae and they are found on penaeid shrimps (Rajkumar et al., 2011). This parasite was firstly described by Nobili (1906) on green tiger shrimp Penaeus semisulcatus De Haan, 1844 from the Red Sea (Rajkumar et al., 2011). After that, $E$. ingens was found in several penaeid species such as $P$. semisulcatus (Rajkumar et al., 2011); (Thomas, 1977), Parapenaeopsis stylifera (H. Milne Edwards, 1837) (Gopalakrishnan et al., 2009); (Thirumilu, 2011), Metapenaeopsis stridulans (Alcock, 1905) (Rajkumar et al., 2011); (Thirumilu, 2011), Metapenaeopsis mogiensis Rathbun, 1902, Parapenaeopsis maxillipedo Alcock, 1905, Penaeus monodon (Fabricius, 1798), Fenneropenaeus indicus (H. Milne Edwards, 1837), Solenocera crassicornis (H. Milne Edwards, 1837) (Thirumilu, 2011), Farfantepenaeus aztecus (Ives, 1891) (Korun et al., 2013), Penaeus merguiensis (De Man, 1888) (Owens, 1987), Penaeus japonicus (Bate, 1888), Penaeus stylirostris (Stimpson, 1874) and Penaeus esculentus (Haswell, 1879) (Gopalakrishnan et al., 2009).

* Corresponding author: Faculty of Fisheries, Akdeniz University, 07058. Antalya, Turkey. Tel: +905358554167

e-mail: gokoglu@akdeniz.edu.tr

doi: http://doi.org/10.29103/aa.v7i1.2091
$E$. ingens has been recorded for the first time in the Mediterranean Sea by Bourdon (1968). After then, the second record for $E$. ingens has been made in the Gulf of Antalya/Mediterranean Sea by Korun et al. (2013). It was observed that an abnormal discolored bulge underside of the right branchiostegite (gill cover) part of the carapace section of the infested shrimp. An abnormal discolored bulge was observed underside of the right branchiostegite (gill cover) part of carapace section of the infested shrimp. When the isopod pair was collected from the gills, the infested shrimp gills were pale and a wide depression was noticed on the gills. This parasite was determined on the F. aztecus by Korun et al. (2013).

F. aztecus is an alien prawn species in the Mediterranean. This prawn is native species in the Western Atlantic coast of U.S.A. from Massachusetts to Texas and East coast of Mexico from Tamaulipas to Campeche (FAO. 2017). This species was introduced to the Mediterranean Sea ecosystem. In the Mediterranean Sea, the northern Brown shrimp was collected for the first time in 2009 in the Antalya Bay, Turkey (Scannella et al., 2017). Since then, the species quickly spread along the coasts of southern Turkey (Scannella et al., 2017); (Gökoğlu \& Özvarol, 2013). This shrimp has been an important species for commercial fishing in the Gulf of Antalya. Recently E. ingens has begun to appear on this shrimp. Initially, this parasite was rarely being seen on these shrimps, but recently it has begun to see abundantly (Teker, 2016). In this study, we aimed to investigate the infestation rate and effects of $E$. ingens on growth and reproduction of brown shrimp F. aztecus in the Gulf of Antalya. 


\section{Materials and methods}

\subsection{Material}

Specimens were collected from Lara offshore (A point$36^{\circ} 46^{\prime} 19.3^{\prime \prime} \mathrm{N}$ - $30^{\circ} 53^{\prime} 19^{\prime \prime} \mathrm{E}$ ) to Side lighthouse (B point$36^{\circ} 44^{\prime} 22.5^{\prime \prime} \mathrm{N}-31^{\circ} 17^{\prime} 12^{\prime \prime} \mathrm{E}$ ) in the Gulf of Antalya (Figure 1) during the commercial trawl operations. Samplings were carried out during the period January 2016 to December 2016.

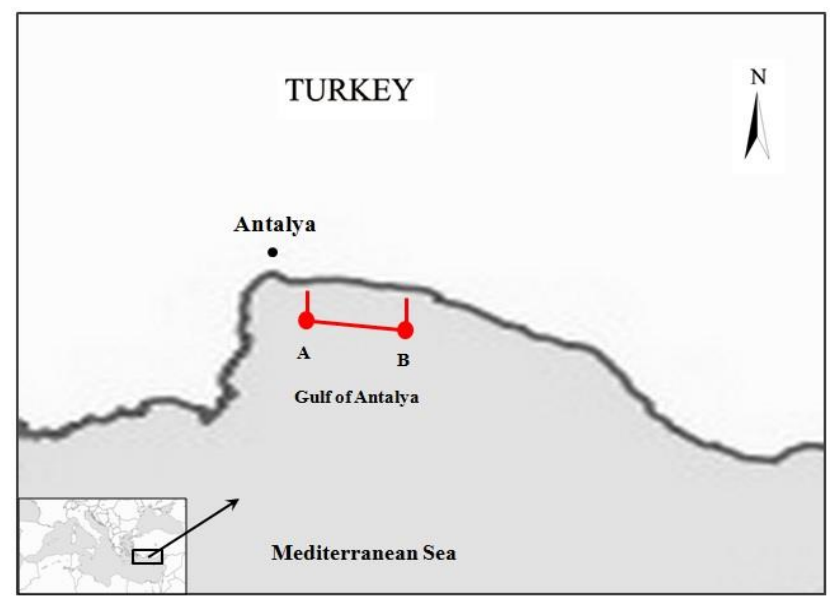

Figure 1. Location of collected samples in Gulf of Antalya

\subsection{Methods}

We examined the branchial cavities on each shrimp as macroscopic for the presence of bopyrid isopod. Each infested and non-infested shrimps were separated and enumerated, sexed, weighted and measured in $0,1 \mathrm{~mm}$ precision.

\subsection{Data analysis}

The relationship between length and weight was calculated using formula $W=a L^{b}$ (Le Cren, 1951) where $W$ is the total weight $(\mathrm{g}), \mathrm{L}$ carapace length $(\mathrm{mm})$ the parameters $a, b$ were calculated functional regression (Beverton \& Holt, 1957). Fulton's condition factor (K) for each individual was calculated according to Htun-Han (1978) equation $\mathrm{K}=100 \times\left(\mathrm{W} / \mathrm{L}^{3}\right)$, where $\mathrm{W}$ is the body weight (BW), and $L$, the carapace length $(\mathrm{CL})$. The $K$ mean values for each type were tested by z-test at the 0.05 significance level to verify that all $K$ values were found to be significant $(P<0.05)$. In addition, Female shrimps were analyzed for gonadal development under the light as macroscopic for the presence of ovarian development according to Lumare and Scordella (2001) and then photographed.

\section{Result and discussion}

In this study, bopyrid isopod parasite E. ingens (Figure 2) was detected on F. aztecus. But, E. ingens was first recorded on $P$. semisulcatus in the Mediterranean by Burdon (1968). It was reported again on F. aztecus in the Mediterranean after 45 years by Korun et al (2013). This parasite is originated from Indo-pacific and it was seen again approximately a half of century later in the Mediterranean Sea. This situation is very interesting. It reminds that bopyrid isopod parasite $E$. ingens was moved to Mediterranean on this exotic shrimp F. aztecus. In this study, $E$. ingens was found to infest $P$. semisulcatus and $P$. kerathurus very rarely. According to Teker (2016) this parasite was not seen on $P$. semisulcatus and $P$. kerathurus which are caught at the same area with $F$. aztecus. The similar results reported by Scannella et al. (2017) that $F$. aztecus might be a vector of spread for the parasite E.ingens to other penaeid species.

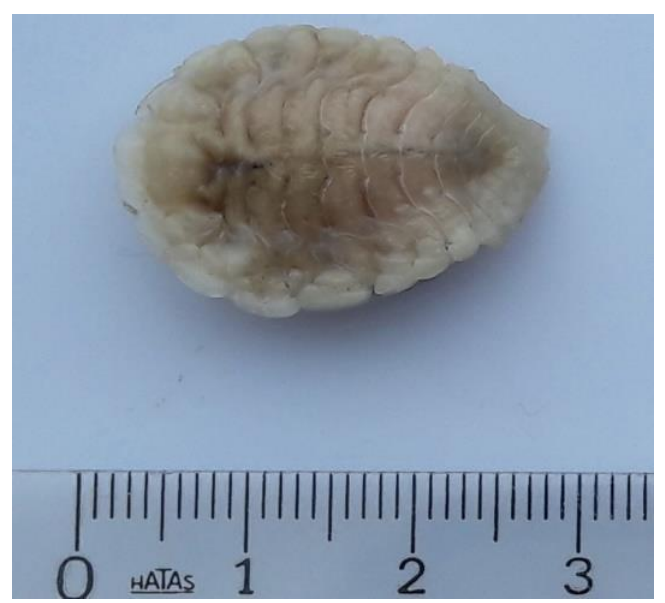

Figure 2. Epipenaeon ingens

\subsection{Infestation rate}

In this study, a total $515 \mathrm{~F}$. aztecus was examined. Total 304 specimens (167 females and 137 males) were found as infested by Epipenaeon ingens (Table 1). The infestation rate was calculated as $59.02 \%$. In this study, generally parasite on the left or right branchial chamber of shrimps was observed however sometimes it was observed on both side branchial chambers (Figure 3). According to Teker (2016) this parasite was rarely seen whereas recently rate of seeing significantly increased. The findings of our study were much higher than the values reported by Rajkumar et al. (2011) for total prevalence and presence of Metapenaeopsis stridulans females of $17.46 \%$ and $28 \%$, respectively.

Table 1

Total number of parasitized and non-parasitized shrimps (F. aztecus) according to sex.

\begin{tabular}{ccccc}
\hline Sex & Parasitized & Non-parasitized & Total & Rate (\%) \\
\hline Male & 137 & 95 & 232 & 45,04 \\
Female & 167 & 116 & 283 & 54,96 \\
Total & 304 & 211 & 515 & 100 \\
Rate (\%) & 59,02 & 40,98 & 100 & \\
\hline
\end{tabular}

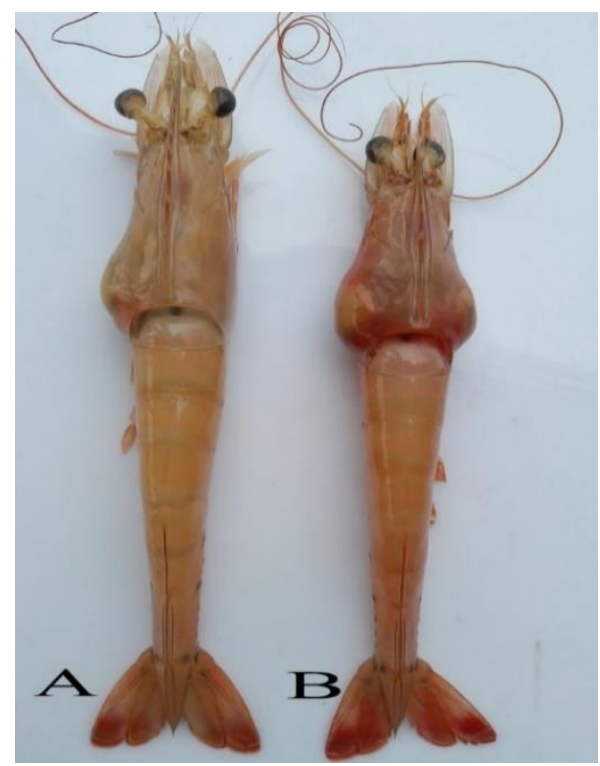

Figure 3. P. aztecus A: One side B: Two side parasitic 


\subsection{Length-weight relationship}

The results of length-weight relationship are shown in Table 2. Generally, the coordinates for parasitized shrimps were fallen down according to the normal length- weight regression line (Figure 4 A-F). In addition, while the " $b$ " parameter of lengthweight relation was 1.991 for infested shrimps, non-infested shrimps the " $b$ " value was 2.544. According to Williams and Boyko (2012); Some species of bopyrids branchially infest decapods and because of their actions as hemolymph and ovarian fluid feeders can be effect of their hosts. Additionally, Gopalakrishnan et al., (2009) report that $E$. ingens pressurize on the host gills and reduced the respiratory efficiency of the host. This effects of parasites to host may be inhibit to growth of host.

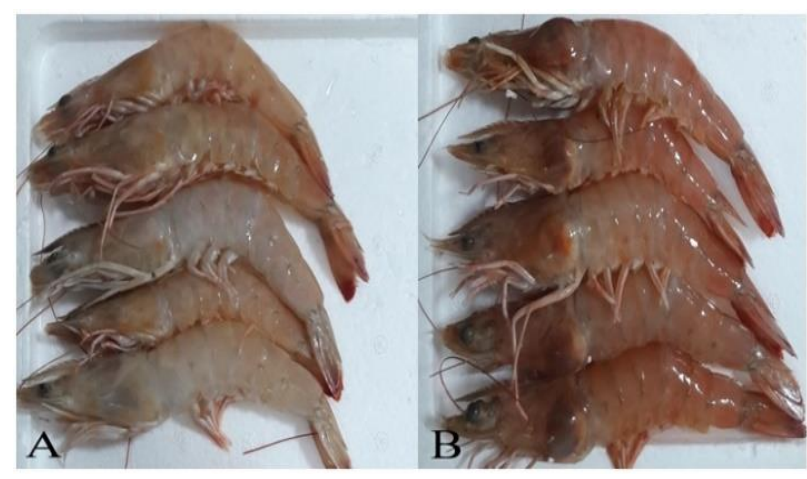

Figure 5. A: Non-parasitized shrimps B: Parasitized shrimps

Table 2

Descriptive statistics and length-weight relationship parameters for parasitized and non-parasitized F.aztecus caught in from Gulf of Antalya

\begin{tabular}{|c|c|c|c|c|c|c|c|c|c|c|}
\hline \multirow{2}{*}{\multicolumn{2}{|c|}{ Samples }} & \multirow{2}{*}{$\mathrm{N}$} & \multicolumn{2}{|c|}{ Carapace length (mm) } & \multicolumn{2}{|c|}{ Total weight $(\mathrm{g})$} & \multirow{2}{*}{ a } & \multirow{2}{*}{ b } & \multirow{2}{*}{$\mathrm{r} 2$} & \multirow{2}{*}{$\begin{array}{c}K \text { mean } \\
(\mathrm{SE})\end{array}$} \\
\hline & & & Min.-Max. & $L$ mean $(\mathrm{SE})$ & Min.-Max. & $W$ mean $(\mathrm{SE})$ & & & & \\
\hline \multirow{3}{*}{ Parasitized } & All samples & 304 & $30-55$ & $39,9 \pm 0,035$ & $21,14-88,30$ & $46,64 \pm 0,963$ & 0,029 & 1,991 & 0,777 & \multirow{3}{*}{$\begin{array}{l}1,053 \\
\pm 0,01\end{array}$} \\
\hline & Male samples & 137 & $33-46$ & $39 \pm 0,044$ & $28,89-65,29$ & $44,29 \pm 1,143$ & 0,009 & 2,288 & 0,806 & \\
\hline & Female samples & 167 & $30-55$ & $40,6 \pm 0,051$ & $21,14-88,30$ & $48,26 \pm 1,397$ & 0,018 & 2,119 & 0,862 & \\
\hline \multirow{3}{*}{ Non-parasitized } & All samples & 211 & $33-65$ & $46,4 \pm 0,875$ & $23,02-135,02$ & $70,65 \pm 3,289$ & 0,003 & 2,544 & 0,955 & \multirow{3}{*}{$\begin{array}{c}1,2 \\
\pm 0,02\end{array}$} \\
\hline & Male samples & 95 & $33-46$ & $39,1 \pm 0,115$ & $23,02-74,39$ & $44,77 \pm 3,661$ & 0,004 & 2,514 & 0,770 & \\
\hline & Female samples & 116 & $34-65$ & $45,9 \pm 0,098$ & $28,96-135,02$ & $69,33 \pm 3,760$ & 0,003 & 2,544 & 0,972 & \\
\hline
\end{tabular}
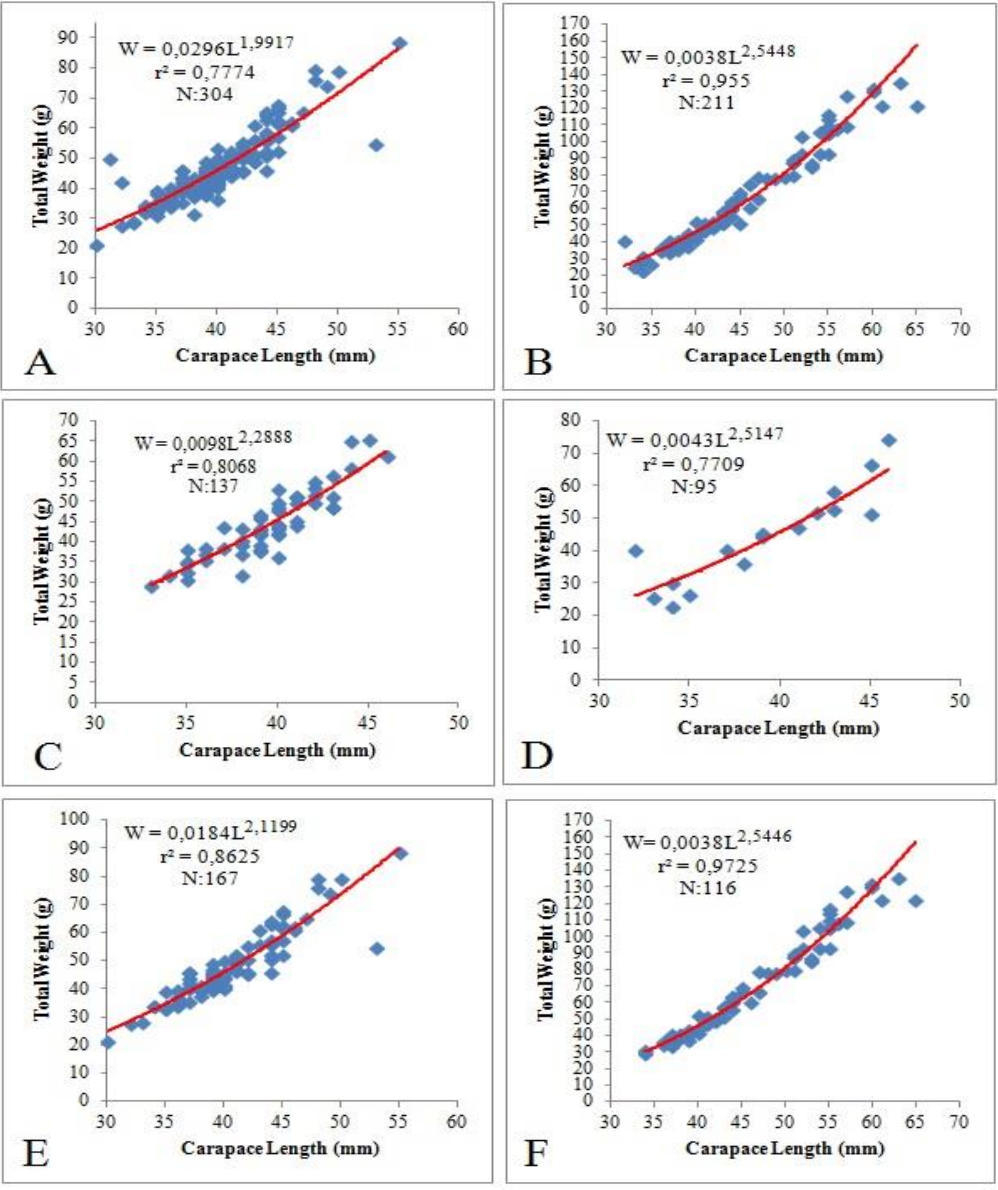

Figure 4. Relationship between carapace length and total weight for (A) all parasitized, (B) all nonparasitized, (C) male parasitized, (D) male non-parasitized, (E) female parasitized, (F) female non-parasitized shrimps from the Gulf of Antalya

\subsection{Condition factor ( $K$ )}

The Condition Factor (K) of F. aztecus samples was 1.05 for parasitized shrimps and 1,20 for non-parasitized ones (Table 2). Table 2 shows that parasitized shrimps are smaller in size and weight than healthy ones. In fact, the variation in the condition factor reflects the sexual maturity and degree of feeding. In this study significant difference in the condition factor values was found. Similarly, Somers \& Kirkwood (1991) stated that growth of parasitized female and male shrimps ( $P$. semisulcatus) was slow.

In this study, the parasitized shrimps had darker and strong shell than those of healthier ones (Figure 5). It is thought that the parasite affected growth of shrimp and it could not change its exoskeleton according to Johnson (1995). In this study, all female specimens were controlled under the light of gonadal maturity and no gonadal development stage was detected in any of the parasitized shrimps whereas gonadal development was observed in different stages of healthy shrimps (Figure 6).

Our findings were supported by Gopalakrishnan et al. (2009) and Rajkumar et al. (2009) who stated that the parasite delayed development of the shrimps and caused degeneration in their sex organs. We think that the parasite which was settles in the gills of the host, affects the anterior and middle lobes of the ovary by some chemical means, increasing the energy load of host and preventing the development of the ovary. 


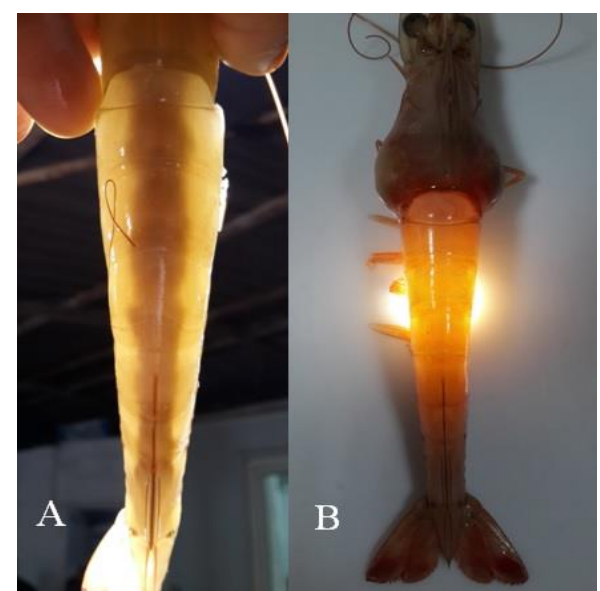

Figure 6. A: Gonadal development stage IV (Non-parasitic) B: No gonadal development (Parasitic)

\section{Conclusion}

The infestation rate shows that bopyrid isopod parasite E. ingens threats to the spawning potential or populations of commercially important shrimp F. aztecus in the Antalya Fishery. As a conclusion, it was determined that $E$. ingens infested $F$. aztecus in the Gulf of Antalya with high rate $(59,02 \%)$. This parasite could affect the growth and reproduction of $F$. aztecus and other shrimp species in the Mediterranean Sea.

\section{Bibliography}

Beverton, R.J.H., Holt, S.J., 1957. On the Dynamics of Exploited Fish Populations.533p. London, UK: Chapman and Hall.

Bourdon, R., 1968. Les Bopyridae des Mers Européennes. Mem. Mus. Natl. Hist. Nat. Paris Nouvelle série Série a Zoologie $L$ (2 et dernier), 50: 75-424.

FAO, 2017. Penaeus aztecus (Ives, 1891) Species Fact Sheets, Fisheries and Aquaculture Department. www.fao.org , FAO Home > Fisheries \& Aquaculture.

Gökoğlu, M., Özvarol Y., 2013. New Mediterranean Marine biodiversity records (December, 2013) 2.15. Biogeographic expansion of Farfantepenaeus aztecus (Ives, 1891) (Decapoda: Penaeidae) in the Eastern Mediterranean Sea. Mediterranean Marine Science 14: 475-476, http://dx.doi.org/10.12681/mms.676

Gopalakrishnan, A., Rajkumar, M., Ravichandran, S., Trilles, J.P., Vasanthan, T.M., 2009. Identification of Parapenaeopsis stylifera, a new host for Epipenaeon ingens. Journal of Environmental Biology. 30(6) 1063-1064.

Htun-Han, M., 1978. The reproductive biology of the dab Limanda limanada (L.) in the North Sea: gonadosomatic index, hepatosomatic index and condition factor. J. Fish Biol., 13(1): 351-377

Johnson, S.K., 1995. Handbook of Shrimp Diseases. Sea Grant Publ. No. TAMU-SG-95-601(r). Texas A\&M University, College Station, TX, 25 pp.

Korun J, Gokoglu M, Balci B.A, Ozvarol Y., 2013. Infestation of brown shrimp, Farfantepenaeus aztecus, Ives (1891) (Penaeidae) by Epipenaeon ingens, Nobili (1906)
(Isopoda, Bopyridae) from the Antalya Bay, Turkey. Revue de Médecine Vétérinaire. 164(12): 559-563.

Le Cren, E.D., 1951. The length-weight relationships and seasonal cycle in gonad weight and condition in perch (Perca fluviatilis). J. Anim. Ecol., 20: 210-219.

Lumare, F., \& Scordella, G., 2001. Ciclo biologico, accrescimento e iproduzione del gambero Penaeidae Melicertus kerathurus della fascia costiera del basso Adriatico. Proceedings of the Int. Works." La Pesca di Paneaus (Melicertus) kerathurus nella costa orientale Italiana e nella lagune, stato attuale, problemi e prospettive", March 16, 2001. Lecce, Italy, 2-14.

Owens, L., 1987. A checklist of metazoan parasites from Natantia (excluding the crustacean parasites of the Caridea). Journal of Shellfish Research, 6: 117-124.

Rajkumar, M., Seerangan, M., Jun, S., Trilles, J.P., 2011. A review of Epipenaeon ingens Nobili, 1906 (Isopoda: Bopyridae) host species and documentation of a new host, Metapenaeopsis stridulans (Alcock, 1905) (Decapoda: Penaeidae). Chinese Journal of Oceanology and Limnology, 29(1):136-140. DOI: 10.1007/s00343-0119923-y.

Scannella, D., Falsone, F., Geraci, M.L., Froglia, C., Fiorentino, F., Giusto, G.B., Zava, B., Insacco, G., Colloca, F., 2017. First report of Northern brown shrimp Penaeus aztecus Ives, 1891 in Strait of Sicily. Biolnvasions Records Vol.6.

Somers, I.F., Kirkwood, G.P., 1991. Population ecology of the grooved tiger prawn Penaeus semisulcatus, in the northwestern Gulf of Carpentaria, Australia: growth, movement, age structure and infestation by the bopyrid parasite Epipenaeon ingens. Australian Journal of Marine and Freshwater Research 42(4): 349-367.

Teker, S., 2016. Determine Some Reproductive Characteristics of Brown Shrimp Farfantepenaeus aztecus, Ives, 1891 Which Originated from Atlantic in The Gulf of Antalya. (MSc Thesis). Akdeniz University. Antalya. (in Turkish).

Thirumilu, P., 2011. Bopyrid parasite Epipenaeon ingens (Nobili, 1906) (Bopyridae, Isopoda) infestation in penaeid shrimps of Cuddalore coast, Tamil Nadu. Research Centre of CMFRI, Chennai. Marine Fisheries Information Service T\&E Ser., P.11-12, ISSN: 0254-380X No. 209.

Thomas, M.M., 1977. A new record of Epipenaeon ingens Nobili (Bopyridae: Isopoda) parasitic on Penaeus semisulcatus Dehann from Palk Bay and Gulf of Mannar. Ind. J. Fish., 24,258

Williams, J.D., Boyko, C.B., 2012. The Global Diversity of Parasitic Isopods Associated with Crustacean Hosts (Isopoda: Bopyroidea and Cryptoniscoidea). PLoS ONE 7(4): e35350. doi:10.1371/journal.pone.0035350 